\title{
Root Zone Microflora is Responsible for Suppressiveness of the White Root Rot Disease in Akwete Rubber Plantations
}

\author{
Ikediugwu FEO ${ }^{1}$ and Ubogu Monday ${ }^{2 *}$ \\ ${ }^{1}$ College of Natural \& Applied Sciences, Igbinedion University Okada, P.M.B 0006, Benin City, Edo State, Nigeria \\ ${ }^{2}$ Department of Biological Sciences, University of Agriculture, Makurdi, P.M.B 2373, Makurdi Benue State, Nigeria
}

\begin{abstract}
The rhizosphere microorganisms of rubber plants (Hevea brasiliensis) were determined using the soil dilution plate method, while the rhizoplane was determined by serial washing of root lengths and plating on PDA plates. Fungi belonging to the genera Aspergillus, Trichoderma, Penicillium, Botryodiplodia and Mucor were isolated from both the rhizoplane and rhizosphere of rubber, at both lyanomo and Akwete rubber plantations. Staphylococcus sp., Bacillus sp. were the only bacteria isolated from the rhizoplane and rhizosphere, together with Bacillus cereus var mycoides, which occurred only on the rhizoplane. A. niger, together with species of Trichoderma, constituted by far the dominant mycoflora in the rhizoplane, at both Iyanomo and Akwete, while A. niger, Penicillium spp. together with Trichoderma spp. dominated at the rhizosphere. In vitro interactions showed that the occurrence of antagonists of $R$. lignosus: Trichoderma spp., Penicillium spp., and Botryodiplodia theobromae, isolated from the root zone of rubber plants were significantly higher at Akwete, than at lyanomo plantations $(P=0.05)$.
\end{abstract}

Keywords: Akwete; Antagonism; Iyanomo; Rhizoplane; Rhizosphere

\section{Introduction}

Much of the rubber latex in world commerce is tapped from the rubber plant, $H$. brasiliensis Mullarg, which is now grown in many tropical regions of the world [1]. In Nigeria, the plant is cultivated in the rain forest belt behind the coastal swamps, the main growing areas being the Midwestern and eastern states of Nigeria [2]. The uses of rubber produce in world economy are numerous, and its use in pneumatic tyres is regarded as the greatest [3].

The rubber tree is prone to many diseases. However, R. lignosus, the causal agent of white root rot disease of rubber, is the pathogen most feared by planters throughout the rubber growing regions of the world [4]. The Rubber Research Institute of Nigeria (RRIN), which maintains two groups of plantations of rubber, one in Iyanomo near Benin, Midwestern Nigeria, and the other in Akwete in Abia State, eastern Nigeria, reported that the white root rot disease continued to be the most serious problem of rubber on the plantations in Iyanomo, where it accounts for $99 \%$ of diseased trees representing nearly $47 \%$ of trees inspected, despite the regular round of inspections and treatments $[5,6]$. On the other hand, Dr. I. K Ugwa and Dr. T. Esekahade, both of the RRIN regard the disease as of no serious concern in the Akwete plantations (Personal Communication). The scenario suggests that the soil at Iyanomo is conducive, while that at Akwete is suppressive to $R$. lignosus, the causal agent of the disease.

Pathogen suppressive soils are found throughout the world. Such soils have been reported in England against take-all disease of wheat by Gaeumanomyces graminis var tritici [7], United States of America against Rhizotocnia stem rot of cauliflower [8], and in Taiwan, against Phytophthora capsici, P. pamivora and P. prasitica [9]. It is in the context of unravelling the basis for the differential response of rubber plants to the disease in the two locations that the present investigation were carried out to determine the microflora of the root zone of the rubber plant, at both Iyanomo and Akwete, as well as their in vitro interactions with $R$. lignosus.

\section{Materials and Methods}

\section{Root sample collection}

Samples of roots of one-year old rubber plants were collected from mature plantations of RRIN, with no history of fertilizer application in Iyanomo and Akwete for microbiological analysis. The age of the sample plants was selected for ease of identification in the field, and of uprooting. The young plants were randomly uprooted from about ten metres radius of the centre of each rubber clone plantation, to minimize possible mingling with seedlings arising from neighbouring clones.

Root samples were collected from clone PB 5/51 of rubber in Iyanomo in May and September, 2004 and in Akwete in June and October of the same year. The spacing in time of sample collection between the locations was to accommodate the long distance apart, and the convenience of laboratory processing. The roots were shaken lightly to detach loosely adhering soil particles, before being taken to the laboratory in polythene bags surface sterilized with $70 \%$ ethanol. The root samples were subjected to microbiological analysis, either soon after arrival in laboratory, or within $24 \mathrm{~h}$ of storage in refrigerator at $4^{\circ} \mathrm{C}$.

\section{Isolation of rhizosphere microorganisms}

Adopting the method of Abdel-Rahim et al. [10], soil particles released following more vigorous shaking of the roots of a batch of 20 rubber plants were collected as the rhizosphere soil. After thoroughly mixing of the soil on sterile filter paper, aliquots of $1.0 \mathrm{~g}$ of soil were

*Corresponding author: Ubogu Monday, Department of Biological Sciences University of Agriculture, Makurdi, P.M.B 2373, Makurdi Benue State, Nigeria Tel: +234-80-6437-1271; E-mail: ubomon@yahoo.co.uk

Received November 07, 2012; Accepted November 28, 2012; Published December 03, 2012

Citation: Ikediugwu FEO, Monday U (2012) Root Zone Microflora is Responsible for Suppressiveness of the White Root Rot Disease in Akwete Rubber Plantations. J Plant Pathol Microb 3:151. doi:10.4172/2157-7471.1000151

Copyright: ( 2012 Ikediugwu FEO, et al. This is an open-access article distributed under the terms of the Creative Commons Attribution License, which permits unrestricted use, distribution, and reproduction in any medium, provided the original author and source are credited. 
suspended in distilled sterile water, to prepare dilutions of $10^{-3}$ or $10^{-5}$ which from preliminary experiment, yielded the best plates for fungal and bacterial colony counting, respectively. One millilitre of $10^{-3}$ or $10^{-5}$ dilutions were plated out in $20 \mathrm{ml}$ molten PDA and swirled to ensure even distribution of inoculum. The PDA plates were amended with a mixture of streptomycin and ampicillin for the isolation of the fungal flora. Ten replicate plates each for bacteria and fungi were incubated at room temperature, bacterial counts being taken after $24 \mathrm{~h}$ and fungal counts between 48-72 h. The microorganisms were identified, and occurrence determined per gram of soil.

\section{Isolation of rhizoplane microorganisms}

The method for isolating root-surface microorganisms was essentially that of Harley and Waid [11], as adapted by Ikediugwu and Ejale [12]. In each round of isolation from either Iyanomo or Akwete, 120 root segments, each $5 \mathrm{~mm}$ in length were excised from both the tap and secondary roots of the batch of 20 rubber plants, and serially washed together twenty times in $100 \mathrm{ml}$ of sterile water, contained in $250 \mathrm{ml}$ conical flask. The flask containing the root segments was shaken vigorously by hand for $2 \mathrm{~min}$ at each wash. Both flask and water were changed up to the fifth wash, but thereafter, only the water was changed. The results of plating out serial washing of roots length of rubber revealed considerable microbial load in the $1^{\text {st }}$ to the $10^{\text {th }}$ washing. While there was no microbial growth in the dilution plates of the $15^{\text {th }}$ to the $20^{\text {th }}$ washing, the results suggest that washing the root length up to the $10^{\text {th }}$ time was adequate in detaching loosely attached propagule from the root surface, and so appropriate for isolating the rhizoplane bacteria and fungi.

One millilitre of the $10^{-1}, 10^{-2}$, and $10^{-3}$ dilutions saved from the first, fifth, tenth, $15^{\text {th }}$ and $20^{\text {th }}$ washes, plated out in $20 \mathrm{ml}$ of Potatoes Dextrose Agar (PDA) were swirled to ensure even inoculum distribution in the PDA plates. Four replicate plates of each dilution were incubated at room temperature $\left(28-30^{\circ} \mathrm{C}\right)$, and bacterial counts were taken after 24 $\mathrm{h}$ and fungal counts between $48-72 \mathrm{~h}$ of incubation, to determine the appropriate number of washings of the root segments for the isolation of the root surface microflora.

Root segments washed for up to 15 times were dried between sheets of sterilized tissue paper and plated out on PDA, six root segments per plate, giving a total of 20 replicate plates for each clone at each sampling. The plates were incubated at room temperature $\left(28-30^{\circ} \mathrm{C}\right)$ for up to seven days, during which bacterial and fungal colonies growing out of the root segments were identified and their frequency of occurrence among the root segments determined.

\section{Screening rhizoplane and rhizosphere microflora for antagonism against $R$. Lignosus, the causal agent of white root rot disease of rubber}

A culture of $R$. lignosus obtained from the laboratory of RRIN, Iyanomo was employed in the present study. Estimation of the degree of antagonism of the isolates against $R$. lignosus was based largely on percentage mycelial extension growth inhibition of the pathogen, as determined using the method of Ferreira et al. [13].

Growth inhibition of $R$. lignosus was calculated using the method of Ferreira et al. [13], the inoculum of each isolates of the species of Penicillium, Mucor and A. niger were placed $3.5 \mathrm{~cm}$ away from the growing edge of the pathogen in $9 \mathrm{~cm}$ Petri dishes. The rhizoplane and rhizosphere bacterial isolates, Bacillus sp., B. cereus var mycoides and Staphylococcus sp., were streaked $2 \mathrm{~cm}$ away from the growing edge of $R$. lignosus in PDA plates. The spacing of the inocula [13], a
$24 \mathrm{~h}$ old culture of the pathogen at room temperature was opposed with individual isolates on PDA plates. Agar disc inoculum of each of the seven isolates of species of Trichoderma and B. theobromae) were inoculated $6.5 \mathrm{~cm}$ away from the growing edge of the colonies of the pathogen in $12 \mathrm{~cm}$ petri dishes, while of the isolates from the pathogen on the plates is related to the extension growth of the individual colonies. Three replicate plates of each of the pairing were incubated at room temperature. Measurement of the mycelial extension growth of R. Lignosus, towards and away from the test antagonist, was made daily. General observations were also made on the growth of the pathogen and the test antagonists on a daily basis. Any zone of inhibition occurring between the organisms was also measured. Percentage mycelial extension growth inhibition of $R$. lignosus was calculated by subtracting distance of mycelial growth towards antagonist, from distance of growth away from antagonist, dividing by mycelial growth away, multiplying this by 100 [13].

\section{Statistical analysis}

Data obtained from replicate plates were calculated using the measure of central tendency (mean) and dispersion (standard deviation). The effect of location on the occurrence of fungal and bacterial isolates from the root zone of the rubber plant were analysed using the Student's t test.

\section{Results}

\section{Fungal and bacterial counts of the rhizosphere of rubber from Iyanomo and Akwete plantations between May and October, 2004}

Microbial counts of the rhizosphere soil of rubber showed that while the bacterial population increased from May to September at Iyanomo, and June to October at Akwete $(\mathrm{p}=0.05)$, the fungal population decreased on both sites (Table 1). However, the decrease observed for fungal counts was statistically significant at Iyanomo $(\mathrm{p}=0.05)$, but not

\begin{tabular}{|l|l|l|l|l|}
\hline & & $\begin{array}{l}\text { Mean microbial } \\
\text { count }\end{array}$ & (cfu/g) \pm SD & \\
\hline & Iyanomo & Akwete & lyanomo & Akwete \\
\hline & (May) & (June) & (September) & (October) \\
\hline
\end{tabular}

\begin{tabular}{l|l|l|l|l}
\hline Bacteria $4.6 \times 10^{5} \pm 1.7 \times 10^{3}$ & $3.8 \times 10^{5} \pm 1.0 \times 10^{4}$ & $3.2 \times 10^{7} \pm 7.0 \times 10^{5}$ & $2.8 \times 10^{7} \pm 5.1 \times 10^{5}$
\end{tabular}

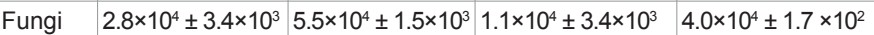

Table 1: Fungal and bacterial counts of the rhizosphere soil of rubber from lyanomo and Akwete plantations between May and October, 2004.

\begin{tabular}{|c|c|c|c|c|}
\hline & $\begin{array}{l}\text { Mean \% } \\
\text { frequency }\end{array}$ & $\begin{array}{l}\text { of occurrence } \\
\pm \text { SD }\end{array}$ & & \\
\hline & Iyanomo & Akwete & Iyanomo & Akwete \\
\hline & (May) & (June) & (September) & (October) \\
\hline \multicolumn{5}{|l|}{ Fungi } \\
\hline A. niger & $75.8 \pm 11.4$ & $44.3 \pm 3.7$ & $47.5 \pm 12.4$ & $17.9 \pm 3.3$ \\
\hline Trichoderma spp. & $18.9 \pm 12.8$ & $51.1 \pm 5.2$ & $30.0 \pm 15.3$ & $57.6 \pm 10.1$ \\
\hline Penicillium spp. & 0.0 & $2.2 \pm 1.6$ & $12.9 \pm 11.3$ & $7.2 \pm 3.4$ \\
\hline B. theobromae & $0.8 \pm 2.6$ & $0.9 \pm 0.1$ & $1.6 \pm 4.5$ & $13.1 \pm 10.7$ \\
\hline Mucor sp. & $4.5 \pm 6.2$ & $1.5 \pm 3.1$ & $8.0 \pm 9.7$ & $4.2 \pm 3.2$ \\
\hline \multicolumn{5}{|l|}{ Bacteria } \\
\hline Bacillus sp. & $18.4 \pm 8.6$ & 0.0 & ND & ND \\
\hline B. cereus var mycoides & $17.4 \pm 8.2$ & 0.0 & ND & ND \\
\hline Staphylococcus sp. & $64.2 \pm 11.1$ & 100.0 & ND & ND \\
\hline
\end{tabular}

ND $=$ Not Determined

Table 2: Mean percentage frequency of occurrence of fungi and bacteria on the Rhizoplane of rubber plant at lyanomo and Akwete plantations. 


\begin{tabular}{|c|c|c|c|c|}
\hline & Microbial counts & (cfu/g) & & \\
\hline & Iyanomo & Akwete & Iyanomo & Akwete \\
\hline & (May) & (June) & (September) & (October) \\
\hline \multicolumn{5}{|l|}{ Fungi } \\
\hline A. niger & $2.5 \times 10^{4}$ & $2.4 \times 10^{4}$ & $6.2 \times 10^{3}$ & $6.4 \times 10^{3}$ \\
\hline Trichoderma spp. & $8.7 \times 10^{2}$ & $5.0 \times 10^{2}$ & $1.4 \times 10^{3}$ & $6.0 \times 10^{3}$ \\
\hline Penicillium spp. & $1.7 \times 10^{3}$ & $3.0 \times 10^{4}$ & $2.8 \times 10^{3}$ & $2.7 \times 10^{4}$ \\
\hline Mucor sp. & $9.0 \times 10^{2}$ & 0.0 & $6.3 \times 10^{2}$ & $8.4 \times 10^{2}$ \\
\hline \multicolumn{5}{|l|}{ Bacteria } \\
\hline B. cereus var mycoides & $4.1 \times 10^{3}$ & 0.0 & ND & ND \\
\hline Staphylococcus sp. & $4.6 \times 10^{5}$ & $3.8 \times 10^{5}$ & ND & ND \\
\hline
\end{tabular}

$\mathrm{ND}=$ Not Determined

Table 3: Occurrence of fungi and bacteria (cfu/g) in the rhizosphere of rubber plants at lyanomo and Akwete plantations.

at Akwete. A comparison of the mean bacterial population between Iyanomo and Akwete as determined in May/June, September/October, respectively, showed that there was no significant difference $(\mathrm{p}=0.05)$ between the two sites. Significantly higher fungal population $(\mathrm{p}=0.05)$ was found at Akwete than Iyanomo.

\section{Occurrence of fungi and bacteria on the rhizoplane and the rhizosphere of rubber at Iyanomo and Akwete}

Fungi belonging to five genera, Aspergillus, Trichoderma, Penicillium, Botryodiplodia and Mucor were encountered in the rhizoplane and the rhizosphere of rubber, at both Iyanomo and Akwete rubber plantations (Table 2 and 3 ).

\section{Rhizoplane}

On the basis of percentage frequency of occurrence, A. niger, together with species of Trichoderma, constituted the dominant mycoflora in the rhizoplane, at both Iyanomo and Akwete. In the study conducted at various times on both sites from May 2004 to October 2004 , it was found that the population of $A$. niger on the rhizoplane decreased, as that of Trichoderma spp. increased (Table 2). Whereas the percentage frequency of occurrence of A.niger in Iyanomo decreased from $75.8 \%$ in May to $47.5 \%$ in September, that of Trichoderma spp. rose from $18.9 \%$ to $30.0 \%$, during the same period of time. Similarly, the percentage frequency of $A$. niger dropped from $44.3 \%$ in June in Akwete to $17.9 \%$ in October, as that of Trichoderma spp. rose from $51.1 \%$ in June to $57.6 \%$ in October of the same year. A comparison made between populations of the two genera of fungi in the rhizoplane in Iyanomo and Akwete in May/June and September/October 2004, showed significant level of difference $(\mathrm{P}=0.05)$, with higher population of A. niger at Iyanomo than Akwete, and higher population of Trichoderma spp. at Akwete than Iyanomo.

The remaining three genera of fungi: B. theobromae, Penicillium spp. and Mucor sp. occurred at much lower frequency of occurrence than Trichoderma spp. and A. niger at both sites (Table 2), and showed hardly any persistent preferences for any of the sites. The population of Penicillium spp. was higher in the rhizoplane in Akwete than Iyanomo in May/June, while the reverse was the case in September/October $(\mathrm{P}=0.05)$. B. theobromae showed a stronger level of occurrence in Akwete in September/October, though their populations between the two sites were comparable in May/June $(\mathrm{P}=0.05)$.

Staphylococcus sp., Bacillus sp. and B. cereus var mycoides were the only bacteria isolated from the rhizoplane of the rubber plant, at both Iyanomo and Akwete plantations in May/June 2004 (Table 2). Staphylococcus sp. was by far, the most predominant bacterial isolate, with a $100 \%$ and $64 \%$ frequency of occurrence on the rhizplane at
Akwete and Iyanomo, respectively. Bacillus sp. and B. cereus var mycoides were encountered only at Iyanomo plantation, with the comparable frequency of occurrence on the rhizoplane of $18.4 \%$ and $17.4 \%$, respectively.

\section{Rhizophere}

Within the period of investigation, May to October, 2004, the populations of A. niger in the rhizosphere decreased significantly at both Akwete and Iyanomo, as against those of Trichoderma spp., which increased significantly at both sites $(\mathrm{P}=0.05)$ (Table 3$)$. In a comparison made between the populations of Trichoderma spp. and A. niger in Akwete and Iyanomo, the latter were found to be comparable throughout the period of investigation $(\mathrm{P}=0.05)$, while Trichoderma spp. showed no considerably higher occurrence for any of the two locations. Furthermore, Penicillium spp. maintained significantly higher populations at the rhizosphere in Akwete than Iyanomo, throughout the period of study. However, while the populations of Penicillium spp. increased significantly with time at Iyanomo, that of Akwete did not show any appreciable changes with time $(\mathrm{P}=0.05) . B$. theobromae was not isolated from the rhizosphere at both sites.

Staphylococcus sp. and Bacillus cereus var mycoides were the only bacteria isolated from the rhizosphere of the rubber plant, at both sites with Staphylococcus sp. showing overriding dominance (Table 3). B. cereus var mycoides was not isolated from the rubber at Akwete.

\section{Antagonism against $R$. lignosus by microbial isolates from the rhizoplane and rhizophere of the rubber plant}

With the exception of species of Mucor, Staphylococcus and B. cereus var mycoides, all isolates of the root zone of the rubber plant from Iyanomo and Akwete plantations exhibited marked mycelial extension growth inhibition in vitro against $R$. Lignosus, the causal agent of white root disease of rubber (Table 4). All the seven isolates of Trichoderma encountered and identified as T. hamatum, T. viride, T. aureoviride and T. polysporium inhibited mycelial extension growth considerably, with percentage inhibition ranging from $26.8 \%$ by $T$. polysporium (PB5/51 Iya) to $44.4 \%$ by T. hamatum (PB 28/59 Akw-Wa) (Table 4). There was no zone of inhibition between $R$. lignosus and any of the isolates of Trichoderma. However, some isolates of Trichoderma, for example, $T$. viride grew over the mycelium of $R$. lignosus.

\begin{tabular}{|c|c|c|}
\hline Microbial Isolates & $\begin{array}{l}\% \text { mycelial growth } \\
\text { inhibition }\end{array}$ & $\begin{array}{l}\text { Zone of inhibition } \\
(\mathrm{mm})\end{array}$ \\
\hline T. hamatum (PB 28/59 Akw-wa) & $44.4 \pm 2.3$ & 0.0 \\
\hline T. hamatum (PB 5/51 lya) & $32.5 \pm 0.7$ & 0.0 \\
\hline T. aureoviride (Akw-fru) & $38.5 \pm 1.3$ & 0.0 \\
\hline T. aureoviride (PB5/51 lya) & $38.0 \pm 0.0$ & 0.0 \\
\hline T. viride ( PB 5/51 Akw) & $29.9 \pm 1.4$ & 0.0 \\
\hline T. viride (5/51 lya) & $27.9 \pm 1.4$ & 0.0 \\
\hline T. polysporium (PB5/51 lya) & $26.8 \pm 0.3$ & 0.0 \\
\hline Penicillium sp²(PB 5/51 Akw-wa) & $22.8 \pm 1.4$ & $10.0 \pm 1.4$ \\
\hline Penicillium sp ${ }^{1}$ (PB 5/51 lya) & $11.4 \pm 0.8$ & $15.0 \pm 0.6$ \\
\hline Penicillium sp'(PB 5/51 Akw-wa) & $19.1 \pm 0.1$ & $12.0 \pm 0.3$ \\
\hline A. niger (PB 5/51 lya) & $21.4 \pm 0.6$ & $12.0 \pm 0.3$ \\
\hline A. niger (PB 5/51 Akw-wa) & $18.1 \pm 1.4$ & $11.0 \pm 1.4$ \\
\hline B. theobromae (PB 5/51 lya) & $48.3 \pm 1.4$ & 0.0 \\
\hline B. theobromae (PB 28/59 Akw) & $42.3 \pm 2.4$ & 0.0 \\
\hline Bacillus sp. & $10.0 \pm 0.3$ & $5.0 \pm 0.7$ \\
\hline B.cereus var mycoides & 0.0 & 0.0 \\
\hline Staphylococcus sp. & 0.0 & 0.0 \\
\hline
\end{tabular}

Table 4: In vitro mycelial extension growth inhibition by the rubber-roots zone isolates against $R$. lignosus. 
Isolates of Penicillium inhibited mycelial extension growth of $R$. Lignosus from a distance, leaving a zone of inhibition ranging from 10-15 $\mathrm{mm}$ between the opposed colonies. There was initially a zone of inhibition ranging from $11.0-12.0 \mathrm{~mm}$ in the interaction between $A$. niger and $R$. Lignosus, which closed up days later with $R$. lignosus growing over the colonies of $A$. niger. Isolates of $B$. theobromae showed percentage mycelial extension growth inhibition, ranging from $42.3 \%$ to $48.3 \%$, with no zone of inhibition developing. Of the bacterial isolates, only the Bacillus sp. inhibited mycelial extension growth by $10 \%$, leaving a zone of $5.0 \mathrm{~mm}$ (Table 4).

\section{Discussion}

While the bacteria counts increased significantly with time at the rhizosphere of the rubber plants at both Iyanomo and Akwete, during the period of study from May to October, 2004, the fungal counts decreased on the both sites. The rising bacteria population coincided with the annual rainfall, which rises to a lower peak in June and a higher peak in September at both Iyanomo and Akwete areas. The observed increasing bacterial population appeared to be associated with increasing water content of the soil. Marschner et al. [14], attributed low microbial population in the rhizosphere of two tropical plants in Central Amazonia (Brazil), during drier months to low water potential, which possess stress for both plants and rhizosphere microorganisms. On the other hand, there is conflicting report of fungal response to water content [14]. Fungal biomass has been reported to positively [15], or negatively [16] correlated with soil water content. Griffin [17], reported that species of Mucor, Aspergillus and Pencillium were isolated with increasing frequency as the water potential decreased, buried plant parts were colonized most frequently by Pythium spp., Mortierella spp., and predacious hypomycetes at water potential exceeding- 1 bar, whereas Gliocladium roseum, Fusarium spp., Trichoderma viride were little affected in range- 4 to 20 bar. Environmental conditions arising from the increasing water content of the soils might have been involved in the observed dynamics of the microorganisms.

The diversity of aerobic bacteria in the rhizosphere and rhizoplane of the rubber plant, in both Iyanomo and Akwete plantations, was found to be low, being made up predominantly of Staphyloccocus sp. Data are not available presently to either explain the predominance of Staphyloccocus sp. at the root zone of the rubber plant, nor the paucity of bacteria diversity. Apart from the isolation of the species of Bacillus and Staphyloccocus from the rhizosphere of wheat, potato and sugar beet plants [18], spring wheat [19], Staphyloccocus sp. has also been reported to occur in the rhizosphere of mangrove plant [20]. The abundance and diversity of bacteria species in the rhizosphere is dependent on the plant species [21].

A. niger, Trichoderma spp., Penicillium spp., B. theobromae and Mucor sp. were the fungi identified to be associated with the root zone of rubber in the present study. Ikediugwu and Ejale [12] found A. niger, B. theobromae, Fusarium solani, Penicillium javanicum, Penicillium spp. and Trichoderma sp. to be consistently associated with root surface of cassava. Penicillium spp., Trichoderma spp. and Fussarium spp. were reported to dominate the rhizosphere mycoflora of wheat and soybean $[19,22]$. The development of the rhizosphere and rhizoplane mycoflora has been attributed to the selective effect imposed on microorganisms, by modification of its immediate soil environment by the roots in several ways, including the excretion of organic substances and dehydration by absorption of water [23]. The degree of tolerance of the microorganisms to excretory substances, as well as competition between the colonizing species, is likely to have played important roles in determining the pattern of occurrence of microorganisms on the roots of rubber tree.

The results of the in vitro studies of the present investigation which showed that the most effective antagonists of $R$. lignosus, namely, Trichoderma spp., Penicillium spp., and B. theobromae, occurred at a higher frequency at the rhizoplane and rhizosphere of rubber in Akwete than at Iyanomo, suggest that the degree of potential protection of rubber root against the white root rot will be greater in Akwete than Iyanomo. The difference in occurrence is most pronounced in respect of Trichoderma spp., with twice the frequency of occurrence at the rhizoplane in Akwete than Iyanomo, and consequently, greater potential of antagonism against the pathogen in the former than the later.

Antagonism of Trichoderma spp. against microorganisms including pathogens has been reported and exploited in biological control of many pathogens [24-27]. Trichoderma spp. antagonizes plant pathogens directly through antibiosis, by virtue of more than 100 metabolites that have antibiotic activities, mycoparasitism and hyphal disruption, or through competition for nutrients/space with the pathogen $[22,26-$ 31]. Although recent discovery has shown that Trichoderma spp. are capable of inducing localized and systemic resistance to a variety of plant pathogen, through induction of terpenoid phytoalexin defense compound in plants, which is toxic to most fungi, but not biocontrol strains of Trichoderma [27], there is no evidence to suggest that this mechanism is of significance, with respect to the white root rot disease under investigation, since Trichodema spp. occurred on the roots of rubber plant at both sites.

The strong in vitro antagonism of $B$. theobromae against $R$. lignosus observed in the present investigation is further noteworthy, as we are not aware of any previous report of $B$. theobromae, with regards to antibiosis. $B$. theobromae has been encountered as rhizoplane microorganism in some tropical crops [12,25], but has been associated with postharvest rot of many tropical crops [12,25,32]. Having already established competence as root surface microorganism of rubber plant, B. theobromae presents itself as a promising candidate for further investigation in biocontrol of white root rot disease of the rubber plant.

Penicillium spp. which was found to be some of the most inhibitory isolates against $R$. lignosus in vitro, attained a much higher level of occurrence at the rhizosphere in Akwete than Iyanomo. Penicillium spp. were reported to be the most dominant saprophytic fungi in the rhizosphere of spring wheat [19], while Pieta \& Patkowska [22], found that antagonists of phytopathogens such as Penicillium occurred more in soybean rhizosphere than in non-rhizosphere soil, and suggested that they have significant influence on the decrease of phytopathogens of soybean. Antibiotic producing antagonistic species of Penicillium have been employed in the control of plant pathogenic fungi $[24,28,33]$. The much higher population of Penicillium spp. in the rhizosphere of rubber in Akwete than at Iyanomo, would suggest that their potential antagonistic pressure on root pathogen of rubber would be greater at Akwete than at Iyanomo.

Although $A$. niger has been shown to be effective in inducing resistance in rice to sheath blight [34], and in the control of the pathogen, Rhizoctonia solani, through antibiosis, overgrowth and hyperparasitism [35], the results of the present study indicate that $A$. niger has a limited capacity as a reliable control agent for R. lignosus, since the later subsequently, overgrew the colony of the former in the in vitro study. Mohammed and Amusa [36] found A. niger to be ineffective in the inhibition of mycelial growth of seedling blight 
Citation: Ikediugwu FEO, Monday U (2012) Root Zone Microflora is Responsible for Suppressiveness of the White Root Rot Disease in Akwete Rubber Plantations. J Plant Pathol Microb 3:151. doi:10.4172/2157-7471.1000151

inducing pathogens of cowpea and maize in vitro test. Furthermore, the higher occurrence of the $R$. lignosus induced white root rot of rubber in Iyanomo plantations $[5,6]$, in spite of high population of $A$. niger at the root zone, indicates a limited efficacy of the latter as a biocontrol agent of the former in the field.

Among the bacteria population encountered at both the rhizoplane and rhizosphere of rubber in the present study, only a Bacillus sp. isolated from the rhizoplane at Iyanomo, but not at Akwete, demonstrated growth inhibition against $R$. lignosus in vitro. However, its presence was at a comparatively low level of occurrence, which probably would limit its impact at the root zone as an antagonist.

The Rubber Research Institute of Nigeria (RRIN) which maintained the two sites of plantations of rubber in Iyanomo and Akwete reported that the white root rot disease incited by R. lignosus, continued to be the most serious problem of rubber on the plantation in Iyanomo, where it accounted for $99 \%$ of the diseased trees (representing nearly $47 \%$ of trees inspected), despite regular rounds of inspections and treatment $[5,6]$. On the other hand, officers of the RRIN regard the white root rot disease as of no serious concern in Akwete plantation (Dr. Ike Ugwa and Dr. T. Esekahade, personal communication). This report suggests that the soil in Akwete plantation is not conducive to the white root rot pathogen, $R$. lignosus.

Suppressive soils have been described for a variety of plant pathogen, including Gaeumannomyces graminis var tritici, Fusarium oxysporium,cereal cyst nematode, Phytophthora cinnamoni, Pythium spp. Rhizoctonia solani, Streptomyces scabies, and Fomes spp. [37,38]. Suppressive soils, for example Fusarium wilt suppressive soils, are known to occur in many regions of the world and are biological in origin [24]. Many genera of bacteria and fungi including Trichoderma spp., non-pathogenic Fusarium spp., Gliocadium spp., Penicillium spp., Pseudomonas spp. and Actinomyces spp. are implicated in natural suppressiveness of soil to pathogens, such as Fusarium oxysporium, $R$. solani, and take-all disease of wheat $[8,19,24,30,31]$, concluded that plants may select for community of microorganisms that protect them from pathogen, and suggested that as an explanation for disease suppression increasing with monoculture. In this connection, Pieta \& Patkowska [22] reported that the proportion of pathogenic fungi in non-rhizosphere soil was almost twice as high, as that in the rhizosphere of soybean, while antagonist isolates of Bacillus sp., Pseudomonas spp., Gliocadium spp., Penicillium spp. an Trichoderma spp. were more than twice higher in the rhizosphere of soybean than non-rhizosphere soil. Furthermore, enhancement of the populations of antagonistic mycoflora, and Trichoderma in particular, at the rhizosphere of rubber through the application of selected fungicides sulfur, organic matter (dry cow manure) was shown to improve the recovery of rubber from Ganoderma root rot disease [39].

The results of the present investigation showed conclusively that the rhizoplane and rhizosphere of rubber plants at Akwete habour a much higher level of occurrence of antagonists of R. lignosus, for example, Trichoderma spp., Penicillium spp., and B. theobromae than at Iyanomo. The much lower occurrence of the white root rot disease caused by $R$. lignosus in Akwete than Iyanomo, probably derives, at least in part, from the quantitative difference in the abundance of the antagonists at the root zone of the rubber plants.

\section{Acknowledgement}

We hereby express our profound gratitude to all the staff at both stations of RRIN, and most especially Dr. IK Ugwa, Dr. I Omorusi, Dr. AA Awah and Dr. T Esekhade, for providing us with useful information and access into the research plantations.

\section{References}

1. Cobley LS (1976) An Introduction to the Botany of Tropical Crops. (2 $2^{\text {nd }}$ Edition), London, Longman Comp. Ltd.

2. Food and Agricultural Organization of the United Nations (FAO) (1966) Agricultural Development In Nigeria 1965-1980. Williams Cloves and Sons Ltd, London.

3. Schery RW (1972) Plants for Man.( $2^{\text {nd }}$ edn), Englewood Cliffs, Prentice-Hall, New Jersey, USA.

4. Pichel RJ (1956) The rot in one's of Hevea in the Congo Basin. INEAC Ser Tech.

5. Rubber Research Institute of Nigeria (RRIN) (1976) Quarterly progress report No. 2, April-June.

6. Rubber Research Institute of Nigeria (RRIN) (1976) Quarterly progress report. No. 4, October-December.

7. Bruehl GW (1987) Soil borne Plant Pathogens. MacMillian Publishing Company, New York.

8. Hancock J, Magyarosy A, Becker JO, Koike S, May D, et al. (1998) Role of soil microbial community in suppression of Rhizoctonia stem rot of cauliflower. Final Report R96. Sustainable Agricultural Research and Education Programme. University of California

9. Ann PJ (1998) Classification and characteristics of Phytophthora-suppressive soils in Taiwan. Proceedings of the $7^{\text {th }}$ International Congress of Plant Pathology (ICPP), Edinburgh, Scotland.

10. Abdel-Rahim AM, Baghadani AM, Abdalla MH (1983) Studies on the fungus flora in the rhizosphere of sugar cane plants. Mycopathologia 81: 183-186.

11. Harley JL, Waid JS (1955) A method of studying active mycelia on living roots and other surfaces in the soil. Transactions of the British Mycological Society 38: $104-118$.

12. Ikediugwu FEO, Ejale AU (1980) Root surface mycoflora of cassava (Manihot esculenta ) and post harvest rot of the tubers. Mycopathologia 71: 67-71.

13. Ferreira JHS, Matthee FN, Thomas AC (1991) Biological Control of Eutypa lata on grapevine by an antagonistic strain of Bacillus subtilis. Phytopathology 81: $283-287$

14. Marschner P, Marino W, Lieberei R (2002) Seasonal effects on microorganisms in the rhizosphere of two tropical plants in a polyculture agroforestry system in Central Amazonia, Brazil. Biol Fertil Soils 35: 68-71.

15. Frey SD, Elliott ET, Paustian K (1999) Bacterial and fungal abundance and biomass in conventional and no-tillage agroecosystem along two climatic gradients. Soil Biol Biochem 31: 573-585.

16. Reichardt W, Briones A, De Jesus R, Padre B (2001) Microbial population shifts in experimental rice systems. Appl Soil Ecol 17: 151-163.

\section{Griffin DM (1972) Ecology of Soil Fungi. Chapman and Hall Ltd, London}

18. Aileen RN, Peter J (2004) The ability of rhizosphere bacteria isolated from nematode host and non-host plants to influence the hatch in vitro of the two potato cyst nematode species, Globodera rostochiensis \& G. pallida. Nematology 6: 375-387.

19. Patkowska $E$ (2002) The role of rhizosphere antagonistic microorganisms in limiting the infection of underground parts of spring wheat. Electronic Journal of Polish Agricultural Universities 5: 1-10.

20. Holguin G, Bashan Y (1996) Nitrogen-fixation by Azospirillium brasilensense $\mathrm{cd}$ is promoted when co-cultured with a mangrove rhizosphere bacterium (Staphyloccocus sp.). Soil Biol Biochem 28: 1651-1660.

21. Berg G, Roskot N, Steidle A, Eberl L, Zock A, et al. (2002) Plant-dependent genotypic and phenotypic diversity of antagonistic rhizobacteria isolated from different Verticillium host plants. Appl Environ Microbiol 68: 3328-3338.

22. Pieta D, Patkowska E (2003) The role of antagonistic fungi and bacteria limiting the occurrence of some phytopathogens inhabiting soybean soil environment Electronic Journal of Polish Agricultural Universities 6: 1-7.

23. Burges A (1958) Microorganisms in Soil. Hutchruson and Co Ltd, London.

24. Larkin RP, Fravel DR (1998) Efficacy of various fungal and bacterial biocontrol organisms for control of Fusarium wilt of tomato. Plant Dis 82:1022-1028. 
Citation: Ikediugwu FEO, Monday U (2012) Root Zone Microflora is Responsible for Suppressiveness of the White Root Rot Disease in Akwete Rubber Plantations. J Plant Pathol Microb 3:151. doi:10.4172/2157-7471.1000151

25. Okigbo RN, Ikediugwu FEO (2000) Studies in biological control of Postharvest rot in yams (Dioscorea spp) using Trichoderma viride. Journal of Phytopathology 148: 351-355.

26. Melo ISD, Faull JL (2000) Parasitism of Rhizoctonia solani by strains of Trichoderma spp. Sci Agric 57: 55-59.

27. Harman GE, Howel CR, Viterbo A, Chet I, Lorito M (2004) Trichoderma species-opportunistic, avirulent plant symbionts. Nat Rev Microbiol 2: 43-56.

28. Parkinson D, Waid JS (1960) The Ecology of Soil Fungi. Liverpool University Press.

29. Dennis C, Webster J (1971) Antagonistic properties of species-groups of Trichoderma: II. Production of volatile antibiotics. Transactions of the British Mycological Society 57: 41-48.

30. Parke J (1996) Biological control of plant pathogens. Midwest Biological Control News 3: 7-9.

31. Kucuk C, Kivanc M (2003) Isolation of Trichoderma spp and detrmination of their antifungal, biochemical and physiological features. Turk J Biol 27: 247253.

32. Ogundana SK, Naqvi SHZ, Ekundayo JA (1970) Fungi associated with sof rot of yam (Dioscorea spp) in storage in Nigeria. Transactions of the British Mycological Society 54: 445-451.
33. Santamarina MP, Rosello J, Llacer R, Sanchis V (2002) Antagonistic activity of Penicillium oxalicum Corrie and Thom, Pencillium decumbens Thom and Trichoderma harzanium Rifai isolates against fungi, bacteria and insects in vitro. Rev Iberoam Micol 19: 99-103.

34. Kandhari J, Majumder S, Sen B (2000) Impact of Aspergillus niger AN27 on growth promotion and sheath blight disease reduction in rice. Int Rice Res Notes 25: 21-22.

35. Sen B, Sharma J, Asalmol MN, Chattopadhyay C, Pastibanda AK (1993) Aspergillus niger-a potential biocontrol agent for soil-borne pathogens. Indian Phytopathology 46: 275.

36. Muhammed S, Amusa NA (2003) In-vitro inhibition of growth of some seedling blight inducing pathogens by compost-inhabiting microbes. Afr J Biotechnol 2 : 161-164.

37. Baker KF, Cook RJ, Garette SD (1974) Biological Control of Plant Pathogens W. H. Freeman and Comp, San Francisco, USA.

38. Raaijmakers JM, Weller DM (2000) Role of antibiotic-producing Pseudomonas spp. in disease suppressive soils. In: Book of Abstracts: Oral Sessions of the $5^{\text {th }}$ International Workshop on PGPR, Cordoba, Argentina.

39. Zakaria MH (1989) Some aspects of the biology and chemically assisted biological control of Ganoderma species in Malaysia. PhD Thesis, Universit Putra Malaysia. 